\title{
ABSTRACTS
}

\section{Constitutional Design and Democratic Performance in Latin America}

\author{
By Fabrice Lehoucq, Mexico City
}

This paper examines the impact of two models of constitutional design on Latin American politics. It suggests that the debate about the advantages and disadvantages of presidentialism needs to move beyond a discussion of whether parliamentary systems last longer than presidential systems. Constitutional design - the way that political systems assign the functions of government among the parts of government - not only affects democratic stability, but also the responsiveness, transparency, and effectiveness of political systems. This essay argues that the checks and balances version of the separation of powers - one that allocates every function of government among two or more parts of government - has contributed not only to political instability, but also impaired political system performance in many countries in the region. It also contends that most presidential systems possess elements of the old with the new separation of powers - a theory of constitutional design assigns one function of government to one part of government. The essay presents evidence that the most successful political systems of the region - Chile, Costa Rica, and Uruguay - are those that depart most significantly from the checks and balances version of the separation of powers.

\section{Introduction of the Property Guarantee in PR China}

By Wenguang $Y u$, Beijing / Frankfurt/M.

The latest constitutional amendment in PR China, approved on March 14, 2004, can be considered a landmark in the development of the Chinese constitution, because the guarantee of private property rights has been integrated into the constitution for the first time. This attracted much attention among the Chinese people and around the world. Yet at the same time there are many questions to answer: Which practical implications for socialist China does the incorporation of property protection into the constitution entail? Which background does this constitutional novella have? Can these new provisions actually be carried out in the future? Which theoretical and practical problems could arise? This article will first introduce the newest constitutional amendment, then outline the historical-political 
context of the introduction of the property protection in the constitution. After this the practical meaning of the amendment is illuminated. Finally, the article takes a look at certain problems with the implementation of the property guarantee in practice and theory, e.g. the interpretation of the concepts of property or property rights and the protective reach of the property guarantee (e.g. social security claims and property problems). Moreover, the constitutional conformity of legal rules with respect to the property guarantee is discussed, as well as the compensation procedure for expropriated or requisitioned property and the connection between the guarantee and other fundamental rights.

The protection of private property in the Chinese constitution has essentially resulted from economic change and social transformation. This way the Chinese constitutional development made considerable progress. Yet because of the above mentioned problems there is still a long way to go for China. Beside the protection of private property, the fair distribution of wealth and the social security system are also of growing relevance. These have come on the agenda of contemporary discussion and their solution will require reforms of the political and social order.

\section{The Constitution of the Republic of China (Taiwan)}

\section{By Mathias Neukirchen, Berlin}

The article starts by introducing the historical, political and international context of the Constitution. The Constitution was originally designed for the whole of China and entered into force 1947. The Chinese civil war (1945-1949) led to the victory of the Red Army on the continental side of China and the retreat of the Guomindang government under General Chiang Kaishek to the island of Taiwan. Since 1949 two Chinese governments, one in Beijing and the other in Taipei, wanted to represent China bilaterally and multilaterally, especially at the level of the United Nations. Originally most states and international organizations such as the United Nations recognized Taipei as the sole legitimate government of China. 1971 was a turning point as from that year on the government in Beijing has been recognized as China's representative government and Taiwan as a part of China.

Both sides of the Taiwan-Strait have always adhered to the One-China-principle, consequently Taiwan has never declared its independence. According to international law Taiwan is therefore not a sovereign state. But because of its factual independence from Beijing, Taiwan cannot be regarded as a regular province of the People's Republic of China. From a legal point of view Taiwan is a de facto regime. As Beijing threatens to reunify China with military force if Taiwan declared its independence, Taiwan sticks to the One-China-Principle and consequently to the constitution of 1947 as a symbol of Chinese unity. 
The article explains the concept of the Constitution of 1947 that goes back to Dr. Sun Yatsen, a national hero on both sides of the Taiwan-Strait. In the third chapter the author outlines the constitutional constraints after the civil war and the alternation of the constitution by the provisional articles during the rule of General Chiang Kaishek and his son. The fourth Chapter deals with the constitutional reforms after the democratisation of Taiwan, and the last chapter depicts important stakes for upcoming constitutional reforms.

\title{
The Expropriations in Zimbabwe and International Public Law
}

\author{
By Wolf Peterhoff, Frankfurt am Main
}

The ethnopolitical conflicts in Africa after the end of the Soviet Union led to the question of the efficiency of international law. Since the year 2000 violence has been perpetrated by state agents on members of the white minority throughout Zimbabwe. Members of the „war-veterans" expelled the white settlers who owned most of the land from their farms. When the farm invasions started in 2000 the police refused to intervene. Furthermore, the government under President Robert Mugabe published presidential decrees, such as the Land Acquisition Bill, under which the expropriations could be executed.

The extralegal expropriations violate principle rules of international public law. Legally, minorities cannot be forced to quit their homes and properties, even if they are allowed to stay in the country.

People and ethnic groups, in this case the white population in Zimbabwe, can be holders of the „Recht auf die Heimat" (Right to the homeland).

There cannot be a priority of the „Recht auf die Heimat“ of the newly settled members of the black majority after the expulsion of the former owners as this would reward expulsion and expropriation which are against international public law. The principle of effectiveness in international public law is not valid after a short period after the expulsion.

Although there is no absolute prohibition of expropriation, the state of Zimbabwe has committed an international crime by promoting and executing the confiscations and therefore has a duty to pay compensation. Generally, for material damages Zimbabwe has to reconstruct the situation by means of full restitution. If the complete elimination of the damage is impossible, then at least compensation has to be paid.

There is a duty to compensate for an expropriation which is in accordance with international public law. The compensation is to be paid to the expropriated promptly, adequately and effectively.

Although the violation of international law cannot be denied, the minority has little prospect of compensation by appealing to international courts. Only the UK can give diplomatic protection and act for the expropriated. 